\title{
VALTIONAPUBULVAANEISTA SIVISTYSTYÖNTEKIJÖIKSI
}

\section{Runsauden ajasta niukkuuteen}

Viimeiset kaksikymmentä vuotta ovat olleet suomalaisen vapaan sivistystyön kannalta merkittävää aikaa. Toiminnan muodot ja määrä ovat kasvaneet voimakkaasti hyvinvointiyhteiskunnan kulutustarpeiden suuntautuessa lisääntyvästi myös sivistyspalveluihin. Lainsäädäntöjä on kehitetty ja yhteiskunnan taloudellinen tuki on laajentunut sen myötä voimakkaasti.

Runsauden sarvi on nyt kuitenkin ehtymässä. Julkisen talouden kiristyminen pakottaa vapaan sivistystyön kilpailemaan voimavaroista muun koulutuksen kanssa. On selvästi nähtävissä oleva tosiasia, että valtion budjetissa rahoituksen painopiste on asettumassa ammatillisen ja virallisen yleissivistävän koulutuksen alueille. Lisäksi koulutuksen tarjonta ja kysyntä alkavat monin osin olla tasapainossa. Löysät on puristettu pois, eivätkä kaikenlaiset rannallamakaamis- ja lohileivänsyöntikurssit siksi enää rekrytoi väkeä. Ihmiset laskevat rahojaan, ovat oppineet kranttuilemaan sisältöjen suhteen, kun kerran valinnan varaa on.

Jatkossa vapaan sivistystyön onkin kyettävä vastaamaan koulutusta etsivien kansalaisten odotuksiin sisällöllisesti täysipainoisella tavalla, mikäli ihmisten mielenkiinto ja yhteiskunnan taloudellinen tuki tarjolla olevia koulutuspalveluja kohtaan aiotaan säilyttää.

Tässä onnistuminen ei ole itsestään selvää. Sen verran uomiinsa jämähtäneitä monet sivistystyön toimintamuodot ja niiden ylläpitäjät ovat.

\section{Kysymys on identiteetistä}

Kysymys on siitä, kykeneekö vapaa sivistystyö säilyttämään sille ominaisen identiteetin ja ke- hittämään sitä ajan vaatimalla tavalla vai sortuuko se toivottomaan kilpailuun hamuamalla Itselleen muodikkaiksikoettuja vieraita tehtäviä, joita jo toiset hoitavat.

Olen asian suhteen hivenen levoton, sillä jäljet pelottavat.

Vapaan sivistystyön historiallista identiteettiä on luonnehtinut kaksi piirrettä. Sisällöltään se on sitoutunut avoimesti arvioihin ja hallinnollisestı se on korostanut mukana olevien toiminnalle asettamien tavoitteiden omaehtoisuutta ja vapautta. Toisin sanoen, ei ole painotettu puolueettoman valistajan roolia eikä ole haluttu sitoutua yhteiskunnan määrittämiin virallisiin koulutustavoitteisiin. Tehtäväksi on ymmärretty demokraattisen yhteiskunnan kulttuurisen moniarvoisuuden vaaliminen. Keskeinen voimanlähde työssä ovat olleet suomalaisessa yhteiskunnassa vaikuttaneet kansanliikkeet omine sivistystarpeineen.

Aiempina vuosikymmeninä näistä liikkeistä keskeisimmin vapaan sivistystyön arvosisältöön vaikuttavia olivat kiistatta kristilliset herätysliikkeet. Viimeisen parin kolmenkymmenen vuoden aikana kuitenkin poliittiset puolueet ja ammattiyhdıstyslıke ovat olleet näkyvimpiä ja ekspansiivisimpia. Sekularisoitunut hyvinvointiyhteıskunta vei ensın uskonnollisilta liikkeiltä kyvyn rekrytoida kansalaisia kasvatuspyrkimystensä pariin ja nyt se näyttää tekevän saman myös yhteiskunnallisten liikkeiden pyrkimyksille.

Mistä on kysymys? Ovatko arvopohjaiset kansanliikkeet täyttäneet historiallisen tehtävänsä, olemmeko tulleet aatteiden kuolemisen aikaan? En usko. Historian todistuksen mukaan aatteet näyttävät kuolevan aina silloin, kun yhteiskunnallinen kehitys etenee ihmisten suunnitelmien mukaisesti ja kaikki näyttää hallitulta. Aatteettomuus ja turvallisuus ovat veljet keskenään. Ne kulkevat käsi kädessä. 
Sen sijaan kriisit nostavat aatteiden arvon. Silloin kaivataan selityksiä sille, miksi kaikki ei tapahtunutkaan siten kun oli ajateltu.

Tällainen tilanne on nyt edessämme maailmanlaajuisesti. Elämme siis aate- ja arvopohdintojen nousun kynnyksellä. Arvopohjaiselle vapaalle sivistystyölle se merkitsee mahdollisuuksia ja haasteita. Tunnustakaamme väriä.

Samanaikaisesti epävarmuuden ajan kanssa on kansalaisten keskuudessa kasvanut myös kriittisyys byrokraattista suunnitteluyhteiskuntaa kohtaan. On väsytty holhoamiseen ja halutaan sen sijaan omaehtoisen valinnan mahdollisuuksia. Tämä heijastuu myös suhtautumisessa kaikkeen sivistystyöhön. Koulutukseltakin kaivataan joustavuutta ja kykyä vastata henkilökohtaisesti määriteltyihin opiskelua ja tulevaisuuden suunnitelmia koskeviin ongelmiin. Näin myös vapaan sivistystyön historiallisen identiteetin toisella ulottuvuudella - toiminnan omaehtoisuudella - näyttää olevan ajankohtainen tilauksensa.

Ongelma ei siten mitä ilmeisimmin olekaan vapaan sivistystyön perinteisen identiteetin elinkelpoisuudessa, vaan kyvyttömyydessämme rakentaa sen varaan, nähdä sen elävä ydin kuolleen pinnan ja muotitrendien alta. Mutta mistä näkökyky?

\section{Laitostuvat opistot}

Kansanopistojen ja kansalais- sekä työväenopistojen muodostamaa vapaan sivistystyön aluetta kutsutaan valtionapupapereissa laitosmuotoiseksi sivistystyöksi. Miten sattuvaa! Surullista on, että näiden opistojen kriittinen reflektio kutsumanimensä suhteen on niin vähäinen. Silmät uummistaen ja esivallan viisauteen luottaen ne ovat antautumassa laitostettaviksi sanan aidossa merkityksessä. Kilvan anotaan valtiovallalta oikeutta antaa virallista kelpoisuutta tuottavaa koulutusta ja valitetaan mahdollisuutta omaehtoiseen tehtävänhakuun. Vapaus ja usko sivistyksen omaehtoisuuteen on korvattu lukio-, peruskoulu-, ammatti- ja yliopistollisten arvosanojen tutkinnoilla. Siitä, mikä tulisi olla sivutehtävä, on tullut elämisen ehto.

Väite on oikeutettu, sillä jo puolet kaikesta opetuksesta kansanopistoissa kuuluu edellä mainittuun ryhmään.

Kansalais- ja työväenopistoissa tällaisen opetuksen osuus ei vielä ole yhtä suuri, mutta vastaavasti siellä on luovuttu sivistyksellisestä kun- nianhimosta sellaisten vuoksi vuodelta kokoontuvien "opintopiirien" hyväksi, joissa vain lähinnä valmistetaan itselle vaatteita ja huonekaluja valtion tuella. Uuden oppimisen ajatus ei kovin merkittävää roolia silloin saa.

Terapialla on oma merkityksensä myös sivistystyössä, mutta se ei voi olla pääasia. Myöskin on ero luovalla, uutta etsivällä käsityöllä ja välittömällä aineellisen edun tavoittelulla, tarpeella kalustaa oma asunto yhteiskunnan tuella. Käsitteet on pidettävä selvinä.

\section{Menneessä riippuvat sivistysjärjestöt}

Sivistysjärjestöjen kannalta 1970-luku oli menestyksen huumaamaa aikaa. Erityisesti näin oli asia puolueiden ja ay-liikkeen ylläpitämien järjestöjen osalta. Puolueet pöyhistelivät voimainsa tunnossa ja itsestään selvää oli, että kaikki yhteiskunnallisesti merkittävä toiminta on poliittisesti sitoutunutta tai ainakin tulisi kohta olemaan. Rahaa oli ja siksi myös sivistysjärjestöt sitä saivat. Niiden piirissä myös aidosti pyrittiin toteuttamaan taustayhteisöjen kannalta merkitseviä sivistyspoliittisia tavoitteita.

Sivistystyön tekijät ja kulttuuriväki parveilivat puolueiden ja ammatillisen liikkeen liepeillä. He tunsivat olevansa tärkeä ja syvästi yhteiskunnallisen tehtävänsä tiedostava ryhmä, jota tulevaisuuden Suomen rakennustyössä kipeästi tarvittiin.

Nyt on tilanne toinen. Puolueet ovat kelkasta pudonneita menneisyyden rudimentteja, joita muutoksen kärjessä uusia tuulia haistelevat kulttuuri-ihmiset vieroksuvat. Suora toiminta on päivän sana. Poliittiset rakenteet natisevat kritiikin alla ja puolueet kokevat itsekın aidosti olevansa yhteiskunnallisessa keskustelussa puolustuksellisessa asemassa. Ne eivät esitä tulevaisuuden visioita, vaan selittävät, miksi kaikki on kuin on.

Tässä tilanteessa myös sivistysjärjestöjen identiteetti on rapistunut ja itsetunto maassa. Kymmenen vuoden takaiset vaatimukset erityisesti poliittisia järjestöjä ja opistoja varten säädettävästä valtionosuudesta tuntuvat unennäöltä. On nöyrrytty muiden järjestöjen kanssa yhteisen kutistuvan kakun jakamiseen.

Ja kun visiot puuttuvat, on alistuttu kalkkeutuneiden taustayhteisöjen rutinoituneen rasvauskoulutuksen valtionapubulvaaneiksi. Ollaan olemassa, että saataisiin valtionapua ja tilastoja. Väki turhautuu ja vähenee työn arvostuksen ja kysynnän laskiessa. 


\section{Kansalaisyhteiskunta tarvitsee rakentajia}

Samanaikaisesti, kun sivistystyön vapaus vapaaehtoisesti hävitetään ja toiminta laitostetaan, kypsyvät yhteiskunnassa syvät muutoksen virrat, joiden kanavaksi ja tulkiksi juuri vapaata sivistystyötä eri muodoissaan tarvitaan.

Rakennemuutosyhteiskunnan epävarmuus, äkkimenestyksen ja ennakoimattoman köyhyyden vuorottelu, ihmisten yksinäisyys ja yksilöllistyvät elämäntavat, kansallisen ja kansainvälisen jännitteet, ympäristökriisit ja perinteisiin demokratian instituutioihin kohdistuva kritiikki ovat oireita tästä. Kaikkialle ulottuva kiihtyvä muutos ei enää anna opiskelijalle mahdollisuutta lopulliseen valmistumiseen. Elämisentaidot ja kyky selviytyä vaativat häneltä jatkuvaa halua ja valmiutta uudistumiseen.

Tässä on vapaan sivistystyön suuri haaste. Sen on tehtävä tästä muuttumisen pakosta vapauden valtakunta. Sen mahdollisuudet piilevät sen kyvyssä muuttaa velvollisuus hyveeksi. Lohtuna on, että sitä tarvitsee syntymässä oleva kansalaisyhteiskunta ja että kysymyksessä on sen perinteinen tehtävä muuttuneissa historiallisissa oloissa.

\section{Yhteistyöllä minuuden etsintåän}

Sekä puolustuksellinen asema suhteessa valtiovaltaan että oman itsetuntemuksen lisääminen puoltavat vapaan sivistystyön kaikkien voimien kokoamista yhteistyöhön katoamassa olevan identiteetin löytämiseksi jälleen. Nyt olisi paikallaan sivistystyön merkitystä ja olemusta pohtiva "Korpilampi-seminaari", jossa muka- na olisivat kaikki työmuodot ja jossa perinteiset reviirirajat ylitettäisiin ennakkoluulottomasti toimintakentän uudenlaisen jäsennyksen löytämiseksi.

Molemmissa opistoryhmissä minuuden etsintä merkitsee kriittistä suhtautumista alistumiseen virallisen koulutusjärjestelmän apulaiseksi. Se merkitsee myös siirtymistä rutinoituneista tehtävistä etsimään uusia sivistystarpeita. Erityisesti kansanopistojen osalta se tarkoittaa myös tietoista omien kansanliiketaustojen antamien voimavarojen etsimistä tai jos niitä ei ole, hakeutumista uusien elävien liikkeiden yhteyteen.

Sivistysjärjestöjen on vuorostaan aika venyttää talutusliekaansa mahoista, aitoja sivistystehtäviä tarjoamaan kykenemättömistä taustajärjestöistä ja vastaavasti etsiä yhteyttä tähän saakka lähinnä vain vastustajiksi koettuihin muihin järjestöihin. Nyt niillä olisi halutessaan (oivaltaessaan?) mahdollisuus ryhtyä yhdessä aidosti moniarvoisen ja omia alakulttuurejaan demokratian perustana arvostavan kansalaisyhteiskunnan rakentajiksi. Tämä vain edellyttää luutuneiden viholliskuvien hylkäämistä ja tietoisen eron tekemistä poliittisten liikkeiden kipeästi tarvitseman sivistystyön ja varsinaisen poliittisen toiminnan välille. Liekö tehtävä ylivoimainen?

Identiteetistään tietoiset vapaan sivistystyön organisaatiot olisivat myös epäilemättä nykyistä tehokkaampi painostusvoima vaadittaessa valtiovallalta varoja toimintaan. Näin ainakin on perusteltua olettaa demokraattista kansalaistoimintaa ja alakulttuurien moninaisuutta arvostavan valtiovallan reagoivan.

Ja meidän valtiovaltammehan perustuu demokratiaan? Perustuuhan? 